\title{
Venenivibrio stagnispumantis gen. nov., sp. nov., a thermophilic hydrogen-oxidizing bacterium isolated from Champagne Pool, Waiotapu, New Zealand
}

Correspondence

Adrian Hetzer

hetzer.adrian@web.de

\author{
Adrian Hetzer, ${ }^{1}$ lan R. McDonald ${ }^{2}$ and Hugh W. Morgan ${ }^{1}$ \\ ${ }^{1}$ Thermophile Research Unit, University of Waikato, Te Whare Wananga o Waikato, Private Bag \\ 3105, Hamilton 3240, New Zealand \\ ${ }^{2}$ Department of Biological Sciences, University of Waikato, Te Whare Wananga o Waikato, \\ Private Bag 3105, Hamilton 3240, New Zealand
}

\begin{abstract}
A novel thermophilic, hydrogen-oxidizing bacterium, designated strain CP.B2 ${ }^{\top}$, was isolated from a terrestrial hot spring in Waiotapu, New Zealand. Cells were motile, slightly rod-shaped, non-spore-forming and Gram-negative. Isolate CP.B ${ }^{\top}$ was an obligate chemolithotroph, growing by utilizing $\mathrm{H}_{2}$ as electron donor and $\mathrm{O}_{2}$ as corresponding electron acceptor. Elemental sulfur $\left(\mathrm{S}^{0}\right)$ or thiosulfate $\left(\mathrm{S}_{2} \mathrm{O}_{3}^{2-}\right)$ was essential for growth. Microbial growth occurred under microaerophilic conditions in 1.0-10.0\% (v/v) $\mathrm{O}_{2}$ [optimum 4-8\% (v/v) $\mathrm{O}_{2}$ ], between 45 and $75{ }^{\circ} \mathrm{C}$ (optimum $70{ }^{\circ} \mathrm{C}$ ) and at $\mathrm{pH}$ values of 4.8-5.8 (optimum pH 5.4). The DNA G+C content was 29.3 mol\%. $16 \mathrm{~S}$ rRNA gene sequence analysis demonstrated that strain CP.B2 ${ }^{\top}$ belonged to the order Aquificales, with a close phylogenetic relationship to Sulfurihydrogenibium azorense (94\% sequence similarity to the type strain). However, genotypic and metabolic characteristics differentiated the novel isolate from previously described genera of the Aquificales. Therefore, CP.B2 ${ }^{\top}$ represents a novel species in a new genus, for which the name Venenivibrio stagnispumantis gen. nov., sp. nov. is proposed. The type strain of Venenivibrio stagnispumantis is CP.B $2^{\top}\left(=\mathrm{JCM} 14244^{\top}=\mathrm{DSM} 18763^{\top}\right)$.
\end{abstract}

The Taupo Volcanic Zone in New Zealand is the terrestrial extension of the Tonga-Kermadec subduction system (Hedenquist, 1986), exhibiting geothermal activities such as fumaroles, steaming grounds, mud pools, geysers and hot springs. Within the Taupo Volcanic Zone, Champagne Pool is one of the largest hot springs. It is around $65 \mathrm{~m}$ in diameter and is located in a 900-year-old hydrothermal eruption crater (Lloyd, 1959). The name Champagne Pool derives from the constant flow of $\mathrm{CO}_{2}$, visible as gas bubbles, buffering the spring water at a $\mathrm{pH}$ of around 5.5. Champagne Pool discharges siliceous geothermal fluid rich in arsenic and antimony at approximately $75^{\circ} \mathrm{C}$ (Jones et al., 2001). Although a few studies have described microbial activity in Champagne Pool in recent years (Ellis et al., 2005; Jones et al., 2001; Mountain et al., 2003; Phoenix et al., 2005), the successful isolation of a micro-organism has not yet been reported. Previous investigations applying cultureindependent approaches, such as denaturing gradient gel

Abbreviation: CTAB, cetyltrimethylammonium bromide.

The GenBank/EMBL/DDBJ accession numbers for the $16 \mathrm{~S}$ rRNA and polA gene sequences of strain CP.B2 ${ }^{\top}$ are DQ989208 and EF581124.

A graph showing the effect of temperature on growth of cells of strain CP.B2 ${ }^{\top}$ is available as supplementary material with the online version of this paper. electrophoresis analysis and construction of clone libraries based on the bacterial 16S rRNA gene, have indicated that isolate CP.B2 ${ }^{\mathrm{T}}$, a member of the order Aquificales, is one of the few dominant micro-organisms present in Champagne Pool (Hetzer et al., 2007).

Currently, the order Aquificales comprises the following genera: Aquifex (Huber et al., 1992), Hydrogenivirga (Nakagawa et al., 2004), Hydrogenobacter (Kawasumi et al., 1984), Hydrogenobaculum (Stöhr et al., 2001) and Thermocrinis (Huber et al., 1998) of the family Aquificaceae; Hydrogenothermus (Stöhr et al., 2001), Persephonella (Götz et al., 2002) and Sulfurihydrogenibium (Takai et al., 2003a) of the family Hydrogenothermaceae; and Balnearium (Takai et al., 2003b), Desulfurobacterium (L'Haridon et al., 1998) and Thermovibrio (Huber et al., 2002) of the family Desulfurobacteriaceae (Euzéby, 1997). Representatives are thermophilic to hyperthermophilic bacteria that commonly colonize geothermally heated environments. Most members of the Aquificales have in common the ability to use the Knallgas reaction $\left(2 \mathrm{H}_{2}+\mathrm{O}_{2} \rightarrow 2 \mathrm{H}_{2} \mathrm{O}\right)$ to yield energy for biosynthesis, therefore using $\mathrm{H}_{2}$ as electron donor and $\mathrm{O}_{2}$ as electron acceptor. On account of their chemolithotrophic metabolism, these organisms are regarded as primary producers of bacterial biomass within high-temperature ecosystems (Huber \& Eder, 2006). 
In the present study, the novel thermophilic bacterium CP.B2 ${ }^{\mathrm{T}}$, isolated from Champagne Pool, was characterized and shown to differ from previously described strains of the order Aquificales.

Geothermal fluid ( $30 \mathrm{~cm}$ below the spring water surface) and sediment $(10 \mathrm{~cm}$ below the water surface) were sampled in September 2005 at the north-east side of Champagne Pool. Samples were collected in sterile 21 glass bottles (Schott) carefully avoiding trapping any air. Within $2 \mathrm{~h}$, samples were transferred into enrichment medium.

Enrichments were performed in a modified version of MSH medium (Aguiar et al., 2004). The medium contained the following components (per litre anaerobic water): $0.15 \mathrm{~g} \mathrm{NaOH}, 0.50 \mathrm{~g} \mathrm{KCl}, 1.36 \mathrm{~g} \mathrm{MgCl}_{2} \cdot 6 \mathrm{H}_{2} \mathrm{O}$, $7.00 \mathrm{~g} \mathrm{MgSO}_{4} .7 \mathrm{H}_{2} \mathrm{O}, 2.00 \mathrm{~g} \quad \mathrm{Na}_{2} \mathrm{~S}_{2} \mathrm{O}_{3} .5 \mathrm{H}_{2} \mathrm{O}, \quad 0.40 \mathrm{~g}$ $\mathrm{CaCl}_{2} \cdot 2 \mathrm{H}_{2} \mathrm{O}, 0.20 \mathrm{~g} \mathrm{NH}_{4} \mathrm{Cl}, 0.25 \mathrm{~g} \mathrm{~K}_{2} \mathrm{HPO}_{4}, 1.95 \mathrm{~g}$ MES and trace minerals, containing (final amounts per litre medium) $5.00 \mathrm{mg}$ disodium EDTA dihydrate, $1.50 \mathrm{mg}$ $\mathrm{CoCl}_{2} .6 \mathrm{H}_{2} \mathrm{O}, \quad 1.00 \mathrm{mg} \quad \mathrm{MnCl}_{2} .4 \mathrm{H}_{2} \mathrm{O}, \quad 1.00 \mathrm{mg}$ $\mathrm{FeSO}_{4} \cdot 7 \mathrm{H}_{2} \mathrm{O}, 1.00 \mathrm{mg} \mathrm{ZnCl}_{2}, \quad 0.40 \mathrm{mg} \mathrm{AlCl}_{3} \cdot 6 \mathrm{H}_{2} \mathrm{O}$, $0.30 \mathrm{mg} \mathrm{Na} \mathrm{WO}_{4} .2 \mathrm{H}_{2} \mathrm{O}, 0.20 \mathrm{mg} \mathrm{CuCl}{ }_{2} .2 \mathrm{H}_{2} \mathrm{O}, 0.20 \mathrm{mg}$ $\mathrm{NiSO}_{4} \cdot 6 \mathrm{H}_{2} \mathrm{O}, 0.10 \mathrm{mg} \mathrm{Na} \mathrm{NeO}_{3}, 0.10 \mathrm{mg} \mathrm{H}_{3} \mathrm{BO}_{3}$ and $0.10 \mathrm{mg} \mathrm{Na} \mathrm{MoO}_{4} \cdot 2 \mathrm{H}_{2} \mathrm{O}$. The $\mathrm{pH}$ value of the medium was adjusted to 5.5. Aliquots of $40 \mathrm{ml}$ and $8 \mathrm{ml}$ were autoclaved under a $\mathrm{CO}_{2}$ atmosphere in $160 \mathrm{ml}$ serum bottles and $30 \mathrm{ml}$ test tubes, respectively. After inoculation using a $5 \%$ inoculum, the initial gas phase was exchanged with $79 \% \mathrm{H}_{2} / 16 \% \mathrm{CO}_{2} / 5 \% \mathrm{O}_{2}$ at $170 \mathrm{kPa}$. Enrichment cultures were incubated at $70{ }^{\circ} \mathrm{C}$. After 2 days incubation without agitation, the medium became turbid due to microbial growth. Serial dilution series on MSH medium solidified by $0.6 \%(\mathrm{w} / \mathrm{v})$ Gelrite gellan gum and $0.06 \%$ (w/v) $\mathrm{MgSO}_{4} \cdot 7 \mathrm{H}_{2} \mathrm{O}$ led to the isolation of CP.B2 ${ }^{\mathrm{T}}$. The purity of the novel isolate was routinely checked by microscopy and 16S rRNA gene sequence analysis.

For scanning electron microscopy, cells were captured on a $0.22 \mu \mathrm{m}$ filter and fixed using $2.5 \%$ glutaraldehyde. The filter was exposed to four changes of $0.1 \mathrm{M}$ sodium cacodylate buffer, rinsed in water and dehydrated in increasing concentrations of ethanol (50,75 and 90\%), followed by four changes of absolute ethanol. The filter was critical-point-dried, sputtered with platinum and viewed using a Hitachi S-4100 field emission scanning electron microscope. The bacterial cells occurred predominantly singly or in pairs. Large cell aggregates were formed in the late-stationary growth phase, macroscopically visible as whitish flocks (Fig. 1a). Cells of isolate CP.B2 ${ }^{\mathrm{T}}$ appeared to have a slightly curved, rod-shaped morphology (Fig. 1bd), with a mean length of $1.30 \pm 0.26 \mu \mathrm{m}$ and a mean width of $0.37 \pm 0.04 \mu \mathrm{m}$. Cells were motile and stained Gramnegative using standard methods (Hucker \& Conn, 1927) with cells of Escherichia coli JM109 as a control. Sporulation was not observed during growth, in 6-month-old cultures or at temperatures above the maximum growth temperature.
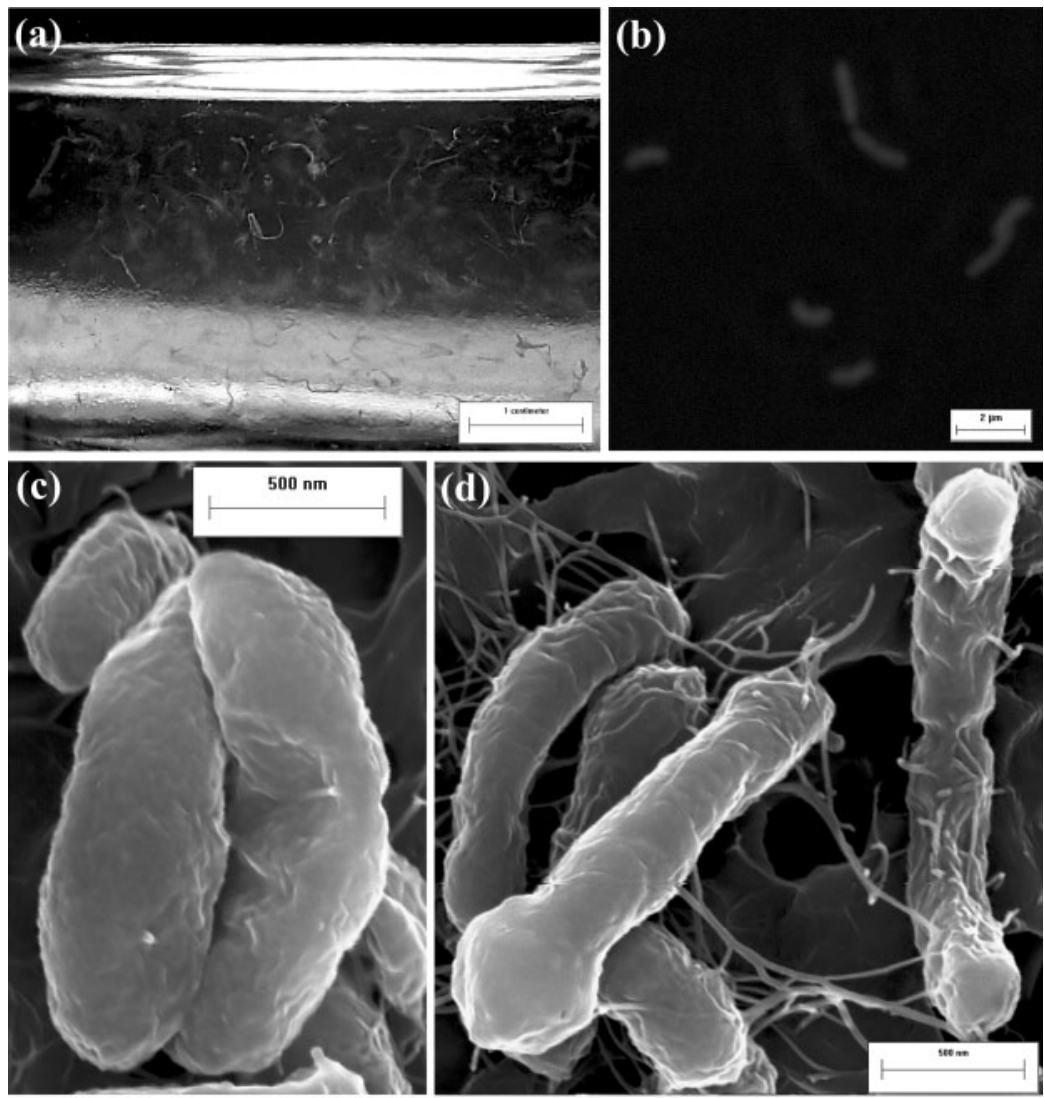

Fig. 1. Macroscopic (a), phase-contrast (b) and scanning electron (c, d) micrographs of isolate CP.B2 ${ }^{\top}$. (a) Large cell aggregates were formed after 2 days incubation in serum bottles; bar, $1 \mathrm{~cm}$. (b) Cells occurred predominantly as single cells or in pairs; bar, $2 \mu \mathrm{m}$. (c, d) Electron micrographs showing vibrio (c) and biofilm-like (d) structures; bars, $500 \mathrm{~nm}$. 
Physiological and metabolic characteristics are summarized in Table 1 and in the genus and species descriptions and were determined as follows. The influence of $\mathrm{pH}$ on growth was determined at $70{ }^{\circ} \mathrm{C}$ at $\mathrm{pH}$ 4.5-6.5 using $10 \mathrm{mM}$ MES, PIPES, MOPS and HEPES. The $\mathrm{pH}$ value of the medium was checked at the incubation temperature prior to inoculation and after the growth experiments. $\mathrm{NaCl}$ and $\mathrm{O}_{2}$ requirements and tolerance were determined at $70{ }^{\circ} \mathrm{C}$ and $\mathrm{pH} 5.5$ at $0-2 \%(\mathrm{w} / \mathrm{v}) \mathrm{NaCl}$ and $0-20 \%(\mathrm{v} / \mathrm{v}) \mathrm{O}_{2}$, respectively. The ability of $\mathrm{CP} . \mathrm{B} 2^{\mathrm{T}}$ to metabolize different substrates was investigated using a basal MSH medium without $\mathrm{Na}_{2} \mathrm{~S}_{2} \mathrm{O}_{3} \cdot 5 \mathrm{H}_{2} \mathrm{O}$ and with only $4.00 \mathrm{~g}$ $\mathrm{MgSO}_{4} \cdot 7 \mathrm{H}_{2} \mathrm{O}$ to provide a sulfur source for assimilation. The basal medium was supplemented with $80 \%(\mathrm{v} / \mathrm{v}) \mathrm{H}_{2}$, $10 \mathrm{mM} \mathrm{Na}{ }_{2} \mathrm{~S}_{2} \mathrm{O}_{3}$ or $1 \%(\mathrm{w} / \mathrm{v}) \mathrm{S}^{0}$ as electron donor and $10 \mathrm{mM} \mathrm{NaNO}_{2}, 10 \mathrm{mM} \mathrm{NaNO}_{3}, 10 \mathrm{mM} \mathrm{Na}_{2} \mathrm{SO}_{3}, 10 \mathrm{mM}$ $\mathrm{Na}_{2} \mathrm{SO}_{4}, 5 \mathrm{mM} \mathrm{Na}_{2} \mathrm{SeO}_{3}, 5 \mathrm{mM} \mathrm{Na}_{2} \mathrm{SeO}_{4}, 5 \mathrm{mM} \mathrm{NaAsO}_{2}$, $5 \mathrm{mM} \mathrm{Na} \mathrm{NaAs}_{4}$ or $\mathrm{O}_{2}$ as complementary electron acceptor. Further experiments were performed using either $1 \mathrm{mM}$ or $5 \mathrm{mM} \mathrm{Na} \mathrm{HAsO}_{4}$ and $\mathrm{NaAsO}_{2}$ as electron acceptor and donor, respectively. Casamino acids, sodium pyruvate, starch, trypticase peptone, yeast extract (final concentration $0.2 \%, \mathrm{w} / \mathrm{v}$ ) or $\mathrm{CO}_{2}$ were provided as carbon source. Isolate CP.B2 ${ }^{\mathrm{T}}$ grew chemolithotrophically under microaerobic conditions utilizing $\mathrm{H}_{2}$, sulfur compounds and $\mathrm{CO}_{2}$ as sole carbon source up to a maximum concentration of $10^{9}$ cells $\mathrm{ml}^{-1}$, with a doubling time of $230 \mathrm{~min}$ (Supplementary Fig. S1, available in IJSEM Online). $\mathrm{H}_{2}$ could not be replaced by other electron donors such as $\mathrm{S}^{0}$ and $\mathrm{S}_{2} \mathrm{O}_{3}^{2-}$ under anaerobic (either $100 \% \mathrm{~N}_{2}$ supplemented with organic substrates or $80 \%$ $\mathrm{N}_{2} / 20 \% \mathrm{CO}_{2}$ ) or microaerobic (either $94 \% \mathrm{~N}_{2} / 6 \% \mathrm{O}_{2}$ with organic carbon sources or $79 \% \mathrm{~N}_{2} / 16 \% \mathrm{CO}_{2} / 5 \% \mathrm{O}_{2}$ ) conditions. However, growth of CP.B2 ${ }^{\mathrm{T}}$ was dependent on either $\mathrm{S}^{0}$ or $\mathrm{S}_{2} \mathrm{O}_{3}^{2-}$ in the medium. Spectrophotometric determination of $\mathrm{H}_{2} \mathrm{~S}$ (Cline, 1969; Gilboa-Garber, 1971) after 24 and $48 \mathrm{~h}$ growth revealed no significant reduction in the quantities of sulfur compounds $(<9 \mu \mathrm{M}$ sulfide) indicating that $S^{0}$ and were not involved in dissimilative metabolism. The strain was not capable of using any of the nine tested electron acceptors in sulfur-limited basal MSH medium providing around $16 \mathrm{mM}$ for assimilation. None of the tested organic compounds were utilized. In all growth experiments, Sulfurihydrogenibium azorense Az$\mathrm{Fu} 1^{\mathrm{T}}$ cultures were used as controls to verify that all solutions and methods were working correctly.

In toxicity experiments, the novel bacterium was tested for tolerance to elevated arsenic and antimony ion levels. Modified MSH medium supplemented with defined concentrations of $\mathrm{Na}_{2} \mathrm{HAsO}_{4} \cdot 7 \mathrm{H}_{2} \mathrm{O}, \mathrm{NaAsO}_{2}$ or $\mathrm{KSbO} . \mathrm{C}_{4} \mathrm{H}_{4} \mathrm{O}_{6} \cdot 0.5 \mathrm{H}_{2} \mathrm{O}$ was inoculated using a $2.5 \%$ inoculum of a freshly grown culture. The MIC was defined as the absence of growth of the species in $30 \mathrm{ml}$ test tubes after 7 days. The isolate displayed growth in the presence of up to $8 \mathrm{mM} \mathrm{NaAsO}$ and $15 \mathrm{mM} \mathrm{KSbO} . \mathrm{C}_{4} \mathrm{H}_{4} \mathrm{O}_{6} \cdot 0.5 \mathrm{H}_{2} \mathrm{O}$ and in the presence of more than $20 \mathrm{mM}$ $\mathrm{Na}_{2} \mathrm{HAsO}_{4} \cdot 7 \mathrm{H}_{2} \mathrm{O}$. Those concentrations are considerably higher than the levels found in Champagne Pool spring water, but lower than levels found in the sediment (Jones et al., 2001): 5.3 p.p.m. $(70 \mu \mathrm{M})$ As and 3.5 p.p.b. $(29 \mathrm{nM})$ $\mathrm{Sb}$ in the pool water and 16700 p.p.m. (223 mM) As and 15600 p.p.m. (128 mM) Sb in the orange sediment. However, growth was not observed when $\mathrm{Na}_{2} \mathrm{HAsO}_{4}$ and $\mathrm{NaAsO}_{2}$ were provided as the sole electron donor and acceptor pair.

Genomic DNA of CP.B2 ${ }^{\mathrm{T}}$ was isolated using a modification of the cetyltrimethylammonium bromide (CTAB) method

Table 1. Comparison of properties of strain CP.B2 ${ }^{\top}$ (Venenivibrio stagnispumantis gen. nov., sp. nov.) with those of related species

Strains: 1, strain CP.B2 ${ }^{\mathrm{T}}$ (Venenivibrio stagnispumantis); 2, Sulfurihydrogenibium yellowstonense SS-5 ${ }^{\mathrm{T}}$ (data from Nakagawa et al., 2005); 3 , Sulfurihydrogenibium azorense Az-Fu1 ${ }^{\mathrm{T}}$ (Aguiar et al., 2004); 4, Sulfurihydrogenibium subterraneum HGMK- $1^{\mathrm{T}}$ (Takai et al., 2003a); 5, Persephonella guaymasensis EX-H2 ${ }^{\mathrm{T}}$ (Götz et al., 2002); 6, Hydrogenothermus marinus $\mathrm{VM}^{\mathrm{T}}$ (Stöhr et al., 2001). Optimal growth conditions are given in parentheses.

\begin{tabular}{|c|c|c|c|c|c|c|}
\hline Characteristic & 1 & 2 & 3 & 4 & 5 & 6 \\
\hline Source & $\begin{array}{l}\text { Terrestrial hot } \\
\text { spring }\end{array}$ & $\begin{array}{l}\text { Terrestrial hot } \\
\text { spring }\end{array}$ & Terrestrial hot spring & Subsurface gold mine & $\begin{array}{c}\text { Hydrothermal } \\
\text { vent }\end{array}$ & $\begin{array}{c}\text { Hydrothermal } \\
\text { area }\end{array}$ \\
\hline \multicolumn{7}{|l|}{ Growth conditions } \\
\hline Temperature $\left({ }^{\circ} \mathrm{C}\right)$ & $45-75(70)$ & $55-78(70)$ & $50-73(68)$ & $40-70(65)$ & $60-80(75)$ & $45-80(65)$ \\
\hline $\mathrm{pH}$ & $4.8-5.8(5.4)$ & $6.0-8.0(7.5)$ & $5.5-7.0(6.0)$ & $6.4-8.8(7.5)$ & $4.7-7.5(6.0)$ & $5.0-7.0$ \\
\hline $\mathrm{NaCl}(\%, \mathrm{w} / \mathrm{v})$ & $0.0-0.8(0.4)$ & $0.0-0.6(0.0)$ & $0.0-0.25(0.1)$ & $0.0-4.8(0.5)$ & $1.0-4.5(2.5)$ & $0.5-6.0(2-3)$ \\
\hline Electron donor(s) & $\mathrm{H}_{2}$ & $\mathrm{~S}^{0}, \mathrm{~S}_{2} \mathrm{O}_{3}^{2-}$ & $\begin{array}{c}\mathrm{H}_{2}, \mathrm{~S}^{0}, \mathrm{~S}_{2} \mathrm{O}_{3}^{2-}, \mathrm{SO}_{3}^{2-} \\
\mathrm{Fe}^{2+}, \mathrm{AsO}_{3}^{3-}\end{array}$ & $\mathrm{H}_{2}, \mathrm{~S}^{0}, \mathrm{~S}_{2} \mathrm{O}_{3}^{2-}$ & $\mathrm{H}_{2}, \mathrm{~S}^{0}, \mathrm{~S}_{2} \mathrm{O}_{3}^{2-}$ & $\mathrm{H}_{2}$ \\
\hline $\begin{array}{l}\text { Electron } \\
\text { acceptor(s) }\end{array}$ & $\mathrm{O}_{2}($ up to $10 \%)$ & $\mathrm{O}_{2}($ up to $18 \%)$ & $\begin{array}{c}\left.\mathrm{O}_{2} \text { (up to } 9 \%\right), \mathrm{S}^{0} \\
\mathrm{~S}_{2} \mathrm{O}_{3}^{2-}, \mathrm{Fe}^{3+}, \mathrm{SeO}_{4}^{2-} \\
\mathrm{AsO}_{4}^{3-}\end{array}$ & $\begin{array}{c}\mathrm{O}_{2}, \mathrm{NO}_{3}^{-}, \mathrm{Fe}^{3+}, \mathrm{SeO}_{3}^{2-}, \\
\mathrm{SeO}_{4}^{2-}, \mathrm{AsO}_{4}^{3-}\end{array}$ & $\begin{array}{c}\mathrm{O}_{2}(\text { up to } 11 \%), \\
\mathrm{NO}_{3}^{-}\end{array}$ & $\mathrm{O}_{2}$ (up to $8 \%$ ) \\
\hline $\begin{array}{l}\text { DNA G + C } \\
\text { content }(\mathrm{mol} \%)\end{array}$ & 29.3 & 32 & 33.6 & 31.3 & 37.4 & 43 \\
\hline
\end{tabular}


described previously (Dempster et al., 1999). A $40 \mathrm{ml}$ bacterial suspension was harvested by centrifugation at $1850 \mathrm{~g}$ (JouanCR4.11) for $10 \mathrm{~min}$. The cell pellet was resuspended in $1 \mathrm{ml}$ CTAB buffer $[100 \mathrm{mM}$ Tris $/ \mathrm{HCl}$, $1.4 \mathrm{M} \mathrm{NaCl}, 20 \mathrm{mM}$ EDTA, $2 \%(\mathrm{w} / \mathrm{v})$ CTAB, $1 \%(\mathrm{w} / \mathrm{v})$ polyvinylpyrrolidone (average molecular mass $360000 \mathrm{Da}$ ) $(\mathrm{pH} 8.0)$ and freshly prepared $0.4 \%(\mathrm{w} / \mathrm{v})$ 2-mercaptoethanol]. The mixture was incubated at $100{ }^{\circ} \mathrm{C}$ for $20 \mathrm{~min}$ followed by extraction with an equal volume of phenol and then with chloroform/isoamyl alcohol $(24: 1, \mathrm{v} / \mathrm{v})$. Nucleic acids were precipitated with an equal volume of 2-propanol and 0.1 vols $3 \mathrm{M}$ sodium acetate $\left(\mathrm{pH} \mathrm{5.5)}\right.$ at $-20{ }^{\circ} \mathrm{C}$ overnight and then washed twice in $70 \%$ ethanol and air-dried.

The $\mathrm{G}+\mathrm{C}$ content of the DNA was determined by the Identification Service of the Deutsche Sammlung von Mikroorganismen und Zellkulturen (DSMZ, Braunschweig, Germany) according to the method of Mesbah et al. (1989). The G $+\mathrm{C}$ content of DNA isolated from strain CP.B2 ${ }^{\mathrm{T}}$ was $29.3 \mathrm{~mol} \%$.

PCR amplification of the 16S rRNA gene sequence between the corresponding E. coli positions 9 and 1522 was performed using forward primer 5'-AGAGTTTGATCCTGGCTCAG- $3^{\prime}$ and reverse primer $5^{\prime}$-AAGGAGGTGATCCARCCGCA-3' (Johnson, 1994). PCR mixtures consisted of PCR buffer $(10 \mathrm{mM}$ Tris/HCl, $50 \mathrm{mM} \mathrm{KCl}$, $\mathrm{pH}$ 8.3), $1.5 \mathrm{mM} \mathrm{MgCl}, 0.2 \mathrm{mM}$ dNTPs (dATP, dCTP, dGTP, dTTP), $1.0 \mu \mathrm{M}$ of each amplification primer, $5.0 \%$ (w/v) DMSO and 1.0 U Taq polymerase (Roche). The following PCR conditions were applied: an initial denaturation step at $94{ }^{\circ} \mathrm{C}$ for $210 \mathrm{~s}$, two cycles of annealing at $50{ }^{\circ} \mathrm{C}$ for $30 \mathrm{~s}$, extension at $72{ }^{\circ} \mathrm{C}$ for $120 \mathrm{~s}$ and denaturation at $94{ }^{\circ} \mathrm{C}$ for $30 \mathrm{~s}$, followed by 31 cycles applying an annealing temperature of $48{ }^{\circ} \mathrm{C}$ for $120 \mathrm{~s}$. The final extension step was $300 \mathrm{~s}$. PCR products purified by agarose gel electrophoresis were used in cloning experiments applying the pGEM-T Easy vector system (Promega) as recommended by the manufacturer. DNA sequencing of the cloned inserts was undertaken by the Waikato DNA Sequencing Facility based at the University of Waikato in Hamilton, New Zealand, using the MegaBase capillary analysis system (Amersham Biosciences). Sequences of the inserts were obtained by using primer set M13pUC forward 5'-CCCAGTCACGACGTTGTAAAACG-3' and M13pUC reverse 5'-AGCGGATAACAATTTCACACAGG-3'. PCR experiments were carried out targeting the DNA polymerase I (polA) gene, which is distinctive in species of the order Aquificales (Griffiths \& Gupta, 2006). DNA extracted from S. azorense $\mathrm{Az}-\mathrm{Fu}^{\mathrm{T}}$ acted as a control.

The BLAST computer algorithm was used to search the sequence database of the National Center for Biotechnology Information (NCBI; http://www.ncbi.nlm.nih.gov) for sequence similarities. Phylogenetic analysis and alignment of $16 \mathrm{~S}$ rRNA gene sequences were performed using the ARB software package (Ludwig et al., 2004). The phylogenetic positions of the sequences were determined using the PHYLIP package with analysis of sequences undertaken using the programs DNADIST, DNAML, DNAPARS, FITCH, NEIGHBOR and SEQBOOT (Felsenstein, 1993). Phylogenetic analysis on the basis of $16 \mathrm{~S}$ rRNA gene sequences indicated that CP.B2 ${ }^{\mathrm{T}}$ is closely related to previously described species of the order Aquificales (Fig. 2). This evidence was supported by sequencing of the polA gene of strain CP.B2 $2^{\mathrm{T}}$; when the sequence was compared with those in GenBank using BLASTX, it showed the highest similarity to PolA from Hydrogenothermus marinus DSM $12046^{\mathrm{T}}$ (sequences of the polA gene of other members of the family Hydrogenothermaceae were not present in the database). Bootstrap analysis of 16S rRNA gene sequences supported the clustering of the novel isolate and members of the genus Sulfurihydrogenibium within the family Hydrogenothermaceae (bootstrap value 100), and clustering of members of the families Hydrogenothermaceae (bootstrap value 77) and Aquificaceae (bootstrap value 95) within the order Aquificales (Fig. 2). Within the order Aquificales, CP.B2 ${ }^{\mathrm{T}}$ displayed the greatest $16 \mathrm{~S}$ rRNA gene sequence similarity $(94 \%)$ to $S$. azorense $\mathrm{Az}-\mathrm{Fu} 1^{\mathrm{T}}$ (Aguiar et al., 2004). However, the novel isolate differed markedly in genotypic and metabolic properties from members of the genus Sulfurihydrogenibium and other genera of the order Aquificales. Although the physiological properties of the novel isolate largely resembled those of members of the genus Sulfurihydrogenibium (Table 1), the $\mathrm{pH}$ range was slightly limited and the optimal $\mathrm{pH}$ value was lower. This might be explained by adaptation of strain CP.B2 ${ }^{\mathrm{T}}$ to its environment. Champagne Pool spring water is buffered by

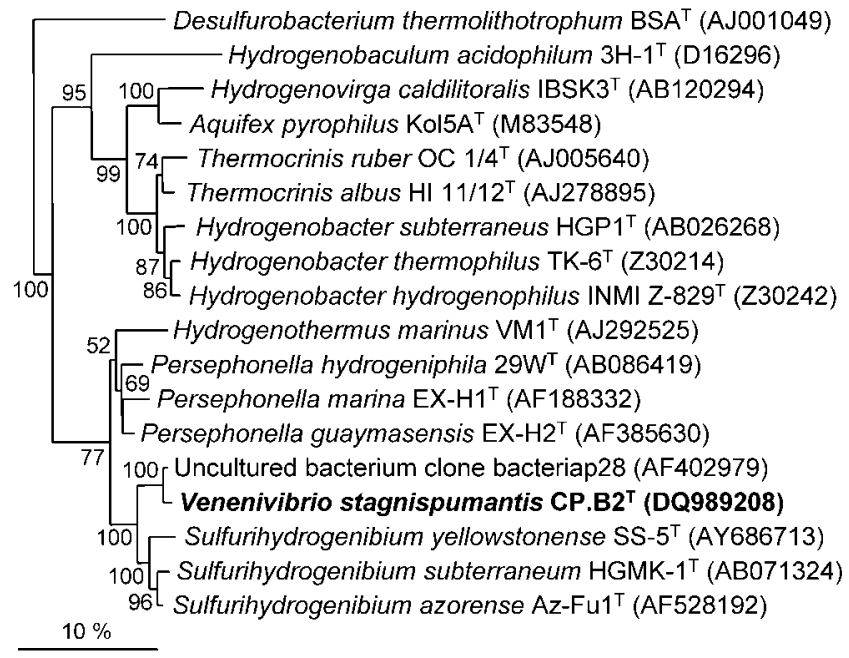

Fig. 2. Phylogenetic tree based on analysis of the $16 \mathrm{~S}$ rRNA gene sequences of strain CP.B2 ${ }^{\top}$ and closely related species of the Aquificales showing the position of the novel isolate. The dendrogram was produced with DNADIST (neighbour-joining) analysis using $1158 \mathrm{bp}$ of aligned sequence. The phylogenetic tree was rooted to Methanococcus jannaschii JAL-1 ${ }^{\top}$ (GenBank accession no. M59126; not shown). Bootstrap values are shown from 1000 replicates. Bar, $10 \%$ sequence divergence. 
a constant flow of $\mathrm{CO}_{2}$, keeping the $\mathrm{pH}$ stable at around 5.5. The low $\mathrm{G}+\mathrm{C}$ content distinguishes it from previously described species of the genera Sulfurihydrogenibium, Persephonella and Hydrogenothermus. To our knowledge, this is the lowest DNA G $+\mathrm{C}$ content reported for a species belonging to the order Aquificales. Strain $\mathrm{CP} . \mathrm{B2}^{\mathrm{T}}$ grew chemolithotrophically under microaerobic conditions utilizing $\mathrm{H}_{2}$ as electron donor, $\mathrm{O}_{2}$ as electron acceptor and $\mathrm{CO}_{2}$ as carbon source. Growth was dependent on $\mathrm{S}^{0}$ or $\mathrm{S}_{2} \mathrm{O}_{3}^{2-}$, but no growth occurred when the sulfur compounds replaced $\mathrm{H}_{2}$ as potential electron donor or $\mathrm{O}_{2}$ as potential electron acceptor. Sulfurihydrogenibium species (Aguiar et al., 2004; Nakagawa et al., 2005; Takai et al., 2003a), Persephonella marina and Persephonella guaymasensis (Götz et al., 2002) are able to use sulfur compounds either as electron donors or acceptors. The hydrogenoxidizing bacterium $H$. marinus requires elemental sulfur for growth as a source for biosynthesis of sulfur-containing compounds (Stöhr et al., 2001) but, like CP.B2 ${ }^{\mathrm{T}}$, cannot use it as a potential electron donor. However, H. marinus can be clearly separated from CP.B2 ${ }^{\mathrm{T}}$. As the name indicates, $H$. marinus is of marine origin and therefore adapted to higher $\mathrm{NaCl}$ concentrations (Table 1).

The occurrence of the novel isolate might not be limited to Champagne Pool in Waiotapu. A $16 \mathrm{~S}$ rRNA gene sequence similarity of $98 \%$ was obtained between CP.B2 ${ }^{\mathrm{T}}$ and a $16 \mathrm{~S}$ rRNA gene clone bacteriap28 amplified from an environmental DNA sample. The DNA sample was extracted from a hot spring in Rotorua, New Zealand (Sunna \& Bergquist, 2003). Rotorua and Waiotapu are both located in the geothermally active Taupo Volcanic Zone, indicating that $\mathrm{CP} . \mathrm{B} 2^{\mathrm{T}}$ and close relatives might be distributed within this zone. Water samples obtained from a hot spring on Fountain Flat $\left(44^{\circ} 33.671^{\prime} \mathrm{N} \quad 110^{\circ} 49.989^{\prime} \mathrm{W}\right)$ in Yellowstone National Park, USA, which features similar chemophysical properties $\left(75^{\circ} \mathrm{C}, \mathrm{pH} 6.2\right)$ to Champagne Pool, were used for enrichment experiments in modified MSH medium. Morphological characteristics of the enrichment cultures differed from those of cells of strain $\mathrm{CP} . \mathrm{B} 2^{\mathrm{T}}$, indicating that $\mathrm{CP} . \mathrm{B} 2^{\mathrm{T}}$ was not present. However, it cannot be ruled out that the novel isolate might be abundant outside New Zealand.

\section{Description of Venenivibrio gen. nov.}

Venenivibrio (Ve.ne' ni.vi'bri.o. L. neut. n. venenum poison; N.L. masc. n. vibrio that which vibrates; N.L. masc. n. Venenivibrio the vibrio of poison).

Cells are slightly curved rods, motile and stain Gramnegative. No sporulation. Microaerophilic. Thermophilic. Strictly chemolithotrophic. Able to utilize molecular hydrogen as electron donor and oxygen as electron acceptor. Either elemental sulfur or thiosulfate is an essential growth requirement. $\mathrm{NaCl}$ is not required for growth. Genomic DNA G + C content is around $29 \mathrm{~mol} \%$. On the basis of 16S rRNA gene sequence analysis, closely related to members of the genus Sulfurihydrogenibium.
Species of the genus Venenivibrio have been detected in terrestrial geothermally heated freshwater systems. The type species is Venenivibrio stagnispumantis.

\section{Description of Venenivibrio stagnispumantis sp. nov.}

Venenivibrio stagnispumantis (stag.ni.spu.man'tis. L. n. stagnum pool; L. part. adj. spumans foaming, frothing; N.L. gen. n. stagnispumantis from a frothing pool, referring to Champagne Pool).

Exhibits the following properties in addition to those described for the genus. Slightly curved rods with a mean length of $1.30 \pm 0.26 \mu \mathrm{m}$ and a mean width of $0.37 \pm 0.04 \mu \mathrm{m}$. Grows at $45-75{ }^{\circ} \mathrm{C}$ and $\mathrm{pH} 4.8-5.8$, with optimum growth at $70{ }^{\circ} \mathrm{C}$ and $\mathrm{pH}$ 5.4. Grows in $0-0.8 \%$ (w/v) NaCl; optimum growth occurs at $0.4 \%(\mathrm{w} / \mathrm{v}) \mathrm{NaCl}$. Tolerates oxygen in the range $1-10 \%(\mathrm{v} / \mathrm{v})$; oxygen is essential for growth. The $16 \mathrm{~S}$ rRNA gene sequence exhibits $94 \%$ similarity to that from the type strain of $S$. azorense.

The type strain is CP.B2 ${ }^{\mathrm{T}}\left(=\mathrm{JCM} 14244^{\mathrm{T}}=\right.$ DSM $\left.18763^{\mathrm{T}}\right)$, isolated from the terrestrial hot spring Champagne Pool in Waiotapu, New Zealand. The DNA G + C content of the type strain is $29.3 \mathrm{~mol} \%$.

\section{Acknowledgements}

The authors wish to thank Christopher J. Daughney for research funding provided by the New Zealand Foundation of Research, Science \& Technology (contract number C05X0303: Extremophilic Micro-organisms for Metal Sequestration from Aqueous Solutions). We are grateful to Richard Fulton for permission to take spring water and sediment samples from Champagne Pool, to Helen M. Turner for the electron microscopy preparation, to Anna-Louise Reysenbach for providing samples of $S$. azorense and to Craig Cary for spring water samples obtained from Yellowstone National Park (permit issued by the National Park Service with support from the National Geographical Society). The help of Hans G. Trüper with naming the novel isolate is greatly appreciated. A. H. thanks his beloved wife for her patience and encouragement. The editor and the two anonymous reviewers offered comments and suggestions that greatly improved this manuscript.

\section{References}

Aguiar, P., Beveridge, T. J. \& Reysenbach, A.-L. (2004). Sulfurihydrogenibium azorense sp. nov., a thermophilic hydrogenoxidizing microaerophile from terrestrial hot springs in the Azores. Int J Syst Evol Microbiol 54, 33-39.

Cline, J. D. (1969). Spectrophotometric determination of hydrogen sulfide in natural waters. Limnol Oceanogr 14, 454-458.

Dempster, E. L., Pryor, K. V., Francis, D., Young, J. E. \& Rogers, H. J. (1999). Rapid DNA extraction from ferns for PCR-based analyses. Biotechniques 27, 66-68.

Ellis, D. G., Bizzoco, R. L. W., Maezato, Y., Baggett, J. N. \& Kelley, S. T. (2005). Microscopic examination of acidic hot springs of Waiotapu, North Island, New Zealand. N Z J Mar Freshw Res 39, 1001-1011. 
Euzéby, J. P. (1997). List of bacterial names with standing in nomenclature: a folder available on the Internet. Int J Syst Bacteriol 47, 590-592.

Felsenstein, J. (1993). PHYLIP (phylogeny inference package) version 3.5c. Distributed by the author. Department of Genome Sciences, University of Washington, Seattle, USA.

Gilboa-Garber, N. (1971). Direct spectrophotometric determination of inorganic sulfide in biological materials and in other complex mixtures. Anal Biochem 43, 129-133.

Götz, D., Banta, A., Beveridge, T. J., Rushdi, A. I., Simoneit, B. R. T. \& Reysenbach, A. (2002). Persephonella marina gen. nov., sp. nov. and Persephonella guaymasensis sp. nov., two novel, thermophilic, hydrogen-oxidizing microaerophiles from deep-sea hydrothermal vents. Int J Syst Evol Microbiol 52, 1349-1359.

Griffiths, E. \& Gupta, R. S. (2006). Molecular signatures in protein sequences that are characteristics of the phylum Aquificae. Int J Syst Evol Microbiol 56, 99-107.

Hedenquist, J. W. (1986). Geothermal systems in the Taupo Volcanic Zone: their characteristics and relation to volcanism and mineralisation. In Late Cenozoic Volcanism, Royal Society of New Zealand Bulletin 23, pp. 134-168. Edited by I. E. M. Smith. Wellington: Royal Society of New Zealand.

Hetzer, A., Morgan, H. W., McDonald, I. R. \& Daughney, C. J. (2007). Microbial life in Champagne Pool, a geothermal spring in Waiotapu, New Zealand. Extremophiles 11, 605-614.

Huber, R. \& Eder, W. (2006). Aquificales. In The Prokaryotes: a Handbook on the Biology of Bacteria, 3rd edn, vol. 7, pp. 925-928. Edited by M. Dworkin, S. Falkow, E. Rosenberg, K. H. Schleifer \& E. Stackebrandt. New York: Springer.

Huber, R., Wilharm, T., Huber, D., Trincone, A., Burggraf, S., Koenig, H., Rachel, R., Rockinger, I., Fricke, H. \& Stetter, K. O. (1992). Aquifex pyrophilus gen. nov., sp. nov., represents a novel group of marine hyperthermophilic hydrogen-oxidizing bacteria. Syst Appl Microbiol 15, 340-351.

Huber, R., Eder, W., Heldwein, S., Wanner, G., Huber, H., Rachel, R. \& Stetter, K. O. (1998). Thermocrinis ruber gen. nov., sp. nov., a pinkfilament-forming hyperthermophilic bacterium isolated from Yellowstone National Park. Appl Environ Microbiol 64, 3576-3583.

Huber, H., Diller, S., Horn, C. \& Rachel, R. (2002). Thermovibrio ruber gen. nov., sp. nov., an extremely thermophilic, chemolithoautotrophic, nitrate-reducing bacterium that forms a deep branch within the phylum Aquificae. Int J Syst Evol Microbiol 52, 1859-1865.

Hucker, G. J. \& Conn, H. J. (1927). Further studies on the methods of Gram staining. N Y State Agric Exp Stn Tech Bull 128, 1-34.

Johnson, J. L. (1994). Similarity analysis of rRNAs. In Methods for General and Molecular Bacteriology, pp. 683-700. Edited by P. Gerhardt, R. G. E. Murray, W. A. Wood \& N. R. Krieg. Washington, DC: American Society for Microbiology.

Jones, B., Renaut, R. W. \& Rosen, M. R. (2001). Biogenicity of goldand silver-bearing siliceous sinters forming in hot $\left(75^{\circ} \mathrm{C}\right)$ anaerobic spring-waters of Champagne Pool, Waiotapu, North Island, New Zealand. J Geol Soc 158, 895-911.

Kawasumi, T., Igarashi, Y., Kodama, T. \& Minoda, Y. (1984). Hydrogenobacter thermophilus gen. nov., sp. nov., an extremely thermophilic, aerobic, hydrogen-oxidizing bacterium. Int $J$ Syst Bacteriol 34, 5-10.

L'Haridon, S., Cilia, V., Messner, P., Raguénès, G., Gambacorta, A., Sleytr, U. B., Prieur, D. \& Jeanthon, C. (1998). Desulfurobacterium thermolithotrophum gen. nov., sp. nov., a novel autotrophic, sulphurreducing bacterium isolated from a deep-sea hydrothermal vent. Int $J$ Syst Bacteriol 48, 701-711.

Lloyd, E. F. (1959). The hot springs and hydrothermal eruptions of Waiotapu. N Z J Geol Geophys 2, 141-176.

Ludwig, W., Strunk, O., Westram, R., Richter, L., Meier, H., Yadhukumar, Buchner, A., Lai, T., Steppi, S. \& other authors (2004). ARB: a software environment for sequence data. Nucleic Acids Res 32, 1363-1371.

Mesbah, M., Premachandran, U. \& Whitman, W. B. (1989). Precise measurement of the $\mathrm{G}+\mathrm{C}$ content of deoxyribonucleic acid by high-performance liquid chromatography. Int J Syst Bacteriol 39, 159-167.

Mountain, B. W., Benning, L. G. \& Boerema, J. A. (2003). Experimental studies on New Zealand hot spring sinters: rates of growth and textural development. Can J Earth Sci 40, 1643-1667.

Nakagawa, S., Nakamura, S., Inagaki, F., Takai, K., Shirai, N. \& Sako, Y. (2004). Hydrogenivirga caldilitoris gen. nov., sp. nov., a novel extremely thermophilic, hydrogen- and sulfur-oxidizing bacterium from a coastal hydrothermal field. Int J Syst Evol Microbiol 54, 2079-2084.

Nakagawa, S., Shtaih, Z., Banta, A., Beveridge, T. J., Sako, Y. \& Reysenbach, A. L. (2005). Sulfurihydrogenibium yellowstonense sp. nov., an extremely thermophilic, facultatively heterotrophic, sulfuroxidizing bacterium from Yellowstone National Park, and emended descriptions of the genus Sulfurihydrogenibium, Sulfurihydrogenibium subterraneum and Sulfurihydrogenibium azorense. Int J Syst Evol Microbiol 55, 2263-2268.

Phoenix, V. R., Renaut, R. W., Jones, B. \& Ferris, F. G. (2005). Bacterial S-layer preservation and rare arsenic-antimony-sulphide bioimmobilization in siliceous sediments from Champagne Pool hot spring, Waiotapu, New Zealand. J Geol Soc 162, 323-331.

Stöhr, R., Waberski, A., Völker, H., Tindall, B. J. \& Thomm, M. (2001). Hydrogenothermus marinus gen. nov., sp. nov., a novel thermophilic hydrogen-oxidizing bacterium, recognition of Calderobacterium hydrogenophilum as a member of the genus Hydrogenobacter and proposal of the reclassification of Hydrogenobacter acidophilus as Hydrogenobaculum acidophilum gen. nov., comb. nov., in the phylum 'Hydrogenobacter/Aquifex'. Int J Syst Evol Microbiol 51, 1853-1862.

Sunna, A. \& Bergquist, P. (2003). A gene encoding a novel extremely thermostable 1,4-beta-xylanase isolated directly from an environmental DNA sample. Extremophiles 7, 63-70.

Takai, K., Kobayashi, H., Nealson, K. H. \& Horikoshi, K. (2003a). Sulfurihydrogenibium subterraneum gen. nov., sp. nov., from a subsurface hot aquifer. Int J Syst Evol Microbiol 53, 823-827.

Takai, K., Nakagawa, S., Sako, Y. \& Horikoshi, K. (2003b). Balnearium lithotrophicum gen. nov., sp. nov., a novel thermophilic, strictly anaerobic, hydrogen-oxidizing chemolithoautotroph isolated from a black smoker chimney in the Suiyo Seamount hydrothermal system. Int J Syst Evol Microbiol 53, 1947-1954. 